\title{
PREVALENCE OF INTESTINAL PARASITES AMONG FOOD HANDLERS IN WESTERN IRAN
}

\author{
Farnaz KHEIRANDISH(1) Mohammad Javad TARAHI(2) \& Behrouz EZATPOUR(3)
}

\begin{abstract}
SUMMARY
Parasitic infection is one of the problems that affect human health, especially in developing countries. In this study, all of the fast food shops, restaurants, and roast meat outlets of Khorramabad (Western Iran) and all the staff employed by them, some 210 people, were selected through a census and their stools were examined for the presence of parasites. The parasitological tests of direct wetmount, Lugol's iodine staining, formaldehyde-ether sedimentation and Trichrome staining techniques were performed on the samples. The data was analyzed with a chi-square test and logistic regression was selected as the analytical model. The results showed 19 (9\%) stool specimens were positive for different intestinal parasites. These intestinal parasites included Giardia lamblia 2.9\%, Entamoeba coli $4.3 \%$, Blastocystis sp. $1.4 \%$, and Hymenolepis nana $0.5 \%$. There was a significant difference between the presence of a valid health card, awareness of transmission of intestinal parasites, participation in training courses in environmental health with intestinal parasites $(p<0.05)$. No statistically significant difference was found between the rate of literacy and gender among patients infected with intestinal parasites $(p>0.05)$. To control parasitic infection in food handlers, several strategies are recommended such as stool examinations every three months, public education, application of health regulations, controlling the validity of health cards and training on parasitic infection transmission. In this regard, the findings of the present study can be used as a basis to develop preventive programs targeting food handlers because the spread of disease via them is a common problem worldwide.
\end{abstract}

KEYWORDS: Intestinal parasite; Food handler; Prevalence; Western Iran.

\section{INTRODUCTION}

Humans have always been in contact with different parasites and one of the hygiene indices of the health of each society is the occurrence of parasites in a population ${ }^{30,31}$. Africa, Asia and the Americas are more affected by these debilitating diseases than other parts of the world ${ }^{31}$. Therefore, contamination with intestinal parasites is a worldwide health problem.

Despite the fact that some parasites are well tolerated in healthy people, other factors debilitate the body through their repetitive damages. For example, Giardia lamblia disturbs the fat absorption process, some worms create anemia, and other parasites (each with special mechanisms, such as sensitivity reactions simultaneously with other diseases) make treatment more difficult and diagnosis more complicated ${ }^{7}$.

With regard to the social, economic and geographical conditions of Iran and its population changes, this country is an appropriate place for the growth and reproduction of all kinds of parasites ${ }^{28}$. In spite of all considerable actions to harness and control parasitical diseases and reduce their occurrences in recent years, contamination with intestinal parasites is one of the problems in this country ${ }^{3,6}$.
The reasons for the incidence of parasites in some parts of the country are: the special climate of the region local traditions and customs, and the use of human and animal fertilizers in agriculture and vegetable planting ${ }^{6}$. In some parasites, infection can be transmitted directly from one infected person to another, and is indirectly transferred through the exchange of tools ${ }^{12}$. Another mode of transmission can be through the contamination of farmlands by human feces due to the use of raw sewage and plant feeding, especially of raw vegetables. This is one of the most important factors of contamination ${ }^{7}$. The other ways are contamination of water by sewage and also the transmission through some insects such as flies and beetles ${ }^{7,16}$. The spread of disease via food handlers is a common and persistent problem worldwide ${ }^{2,27}$.

If food handlers are contaminated with parasites which have the potential to be directly transmitted from one person to another, they can transmit contamination to food, dishes and finally to the people who use them ${ }^{5}$. It is necessary to note that infected persons act as carriers after imperfect treatment; therefore parasites can be transferred from these persons to others 5 .

Food sold in markets may be contaminated by hands that have not been washed after defecation or from flies that land on both food and

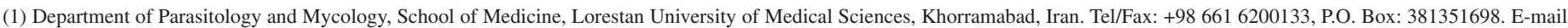
kheirandish81@yahoo.com

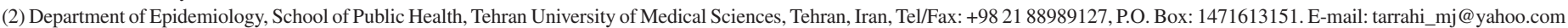

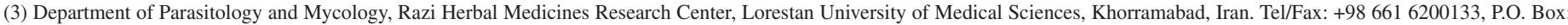
381351698. E-mail: bezatpour@gmail.com

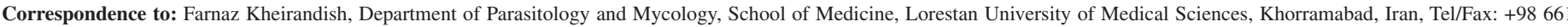
6200133, P.O. Box: 381351698. E-mail: Kheirandish81@yahoo.com 
feces hence increasing the risk of transmission of intestinal parasites for consumers ${ }^{19}$. Healthy preparation, transportation, preservation and distribution of food can help prevent food contamination ${ }^{10,11}$. Food handlers with poor personal hygiene and inadequate knowledge on food safety could be the source of food borne pathogens ${ }^{14}$.

Regarding the patients and complications of parasitic diseases, the importance of their eradication or control becomes more evident. This is possible by identification and detailed study of the geographical distribution as well as ratio of contamination and effects of different cultural, social, and geographical factors. The aim of this study was to assess the prevalence of parasitic infections and make the association of positivity with some epidemiological factors.

\section{METHODS}

Study area: Khorramabad, located in Western Iran, has a population of 487,187 inhabitants, and 210 staff of fast food shops, roasted meat shops, and restaurants, according census in 2011.

Feces collection and analysis: All food handlers in Khorramabad were investigated. Out of the 210 individuals included in this study, 184 $(87.6 \%)$ were men and $26(12.4 \%)$ women. The median age of the patients was 31 with a range of 16 to 60 years. To select the samples, a census method was used so that the stools of all the mentioned staff were taken.

The questionnaire was prepared on the basis of gender, age, literacy rate, awareness of intestinal parasitical disease transmission, validity of health cards and participating in training courses in environmental health.

People who constantly work in the deli have a health card, which is issued by the health deputy of the university of medical sciences and should be checking for infectious and contagious diseases every six months. If a person is infected, immediately take them to a doctor and until they are fully cured, they are not allowed to work. But people who work as temporary workers do not have this card and if they have a parasitic infection, this can be hazardous for others.

Completion of the questionnaires and the collecting of the samples were performed by people who have been trained for this purpose. They attended the places, completed the questionnaires, delivered the stool containers to the staff, collected the containers from them the following morning, and delivered them immediately to the research laboratory of Lorestan University of Medical Sciences.

The parasitological test of direct wet-mount, Lugol's iodine staining, formaldehyde-ether sedimentation and Trichrome staining techniques were performed on the samples ${ }^{9}$. The guide for diagnosis of intestinal parasites was used as an identification reference ${ }^{32}$.

Statistical analysis: The data was analyzed with chi-square test and logistic regression was selected as the analytical model. R software was used to calculate ORs, 95\% confidence intervals (CI) and associated $p$ values $^{22}$. Univariate analyses were performed to assess the effect of individual factors on contamination, then a multivariate model was fitted to identify independent predictors of poor outcomes. Backwards elimination procedures were performed within each domain, with explanatory variables carried forward from each domain that were either significant $(p<0.05)$ or borderline significant $(0.05<p<0.2)$. The final regression model included only those variables that were independently significant at the $5 \%$ level.

\section{RESULTS}

The prevalence of intestinal parasites in 210 stool samples was $9 \%$. The results of our study showed that contamination with intestinal worms and protozoa were $0.5 \%$ and $8.5 \%$, respectively. Also occurrence of pathogenic and nonpathogenic parasites was $4.8 \%$ and $4.2 \%$, respectively.

Intestinal parasites included Giardia lamblia 2.9\%, Entamoeba coli $4.3 \%$, Blastocystis sp. $1.4 \%$, and Hymenolepis nana $0.5 \%$.

Out of the 210 food handlers, $190(90.47 \%)$ had a health card and $10(9.53 \%)$ did not. Of the 190 health card holders, $164(86.32 \%)$ had valid dates and 26 (13.68\%) did not have valid dates.

Out of 210 food handlers, 209 of them answered the question about awareness of intestinal parasites transmission. There was a significant difference between validity date of health card, awareness of intestinal parasites transmission, participation in training courses in environmental health with intestinal parasites $(p<0.05)$. No statistically significant difference was found between rate of literacy and gender among patients infected with intestinal parasites $(p>0.05)$. These variables were entered in the regression model. The results of univariate conditional logistic regression analyses were shown in Table 1.

Awareness of the transmission of intestinal parasitical diseases was due to the influence of participating in training courses and also the observation of the collinearity between the two. The variable of participating in training courses was not used in the logistic regression model. Odds ratio of having a valid health card and the awareness of intestinal parasites transmission was 0.08 and 0.07 , respectively (Table 1).

\section{DISCUSSION}

Parasitic infection is one of the problems that affect human health, especially in developing countries ${ }^{30,31}$. Different studies have been conducted in the field of intestinal parasite prevalence in food handlers ${ }^{19,29}$. In this study, the low prevalence of intestinal parasites found in the food handlers is different from what was reported by other authors in different parts of the world ${ }^{19,29}$.

The study was conducted in Khorramabad on 816 bakery workers and the results showed 96 (11.9\%) stool specimens were positive for different intestinal parasites ${ }^{15}$. The prevalence of intestinal parasites in bakery workers and food handler were almost identical. It may be due to the similarity of conditions.

The results of our study showed that contamination with protozoa was greater than that by helminthes. Similar studies about the prevalence of intestinal parasites were conducted on food handlers, in which some results are the same, and showed protozoan infections were more common than worm infections ${ }^{3,8,24,26,29}$. One reason for this is that transfer of protozoa is much easier than the transfer of the eggs or larvae of worms $s^{13,25}$. In this study, the rates of infection with pathogenic and non-pathogenic parasites were similar (4.8\% and $4.2 \%$ respectively). 
Table 1

Prevalence of intestinal parasites according to epidemiological factors observed in staff of fast food shops, roasted meat shops, and restaurants in Khorramabad city, West of Iran, in 2011

\begin{tabular}{|c|c|c|c|c|}
\hline Variable & No. of samples & Frequency of contamination & Odds Ratio (95\% CI) & $p$-value \\
\hline \multicolumn{5}{|l|}{ Gender } \\
\hline Male & 184 & $9.24 \%(17 / 184)$ & Ref. & \\
\hline Female & 26 & $7.69 \%(2 / 26)$ & $0.85(0.08-4.1)$ & 0.797 \\
\hline \multicolumn{5}{|l|}{ Level of education } \\
\hline Low literate & 104 & $7.69 \%(8 / 104)$ & Ref. & \\
\hline Diploma & 93 & $10 / 75 \%(10 / 93)$ & $1(0.11-8.7)$ & 1 \\
\hline Academic degree & 13 & $7.69 \%(1 / 13)$ & $1.45(0.17-12.32)$ & 0.74 \\
\hline \multicolumn{5}{|l|}{ Age group (years) } \\
\hline$>25$ & 59 & $3.39 \%(2 / 59)$ & Ref. & \\
\hline $25-40$ & 114 & $11.4 \%(13 / 114)$ & $0.29(0.05-1.67)$ & 0.165 \\
\hline $40-70$ & 37 & $10.81 \%(4 / 37)$ & $1.06(0.32-3.48)$ & 0.921 \\
\hline \multicolumn{5}{|c|}{ Awareness of diseases transmission } \\
\hline No & 34 & $38.23 \%(13 / 34)$ & Ref. & \\
\hline Yes & 175 & $3.43 \%(6 / 175)$ & $0.07(0.2-0.23)$ & 0.001 \\
\hline \multicolumn{5}{|c|}{ Holding valid health card } \\
\hline No & 26 & $30.77 \%(8 / 26)$ & Ref. & \\
\hline Yes & 164 & $3.05 \%(5 / 164)$ & $0.08(0.02-0.32)$ & 0.001 \\
\hline
\end{tabular}

This may be an indicator of poor health care and this makes possible the transmission of pathogenic parasites. There are different reports on the prevalence of intestinal parasitic infection in men and women. Some of them are more common in men and by contrast, some are more common in women ${ }^{1,3,20,21,23}$. But in this study no significant difference was found between the sexes among patients infected with intestinal parasites. In some studies that were conducted in other areas, several effective issues were reported in the reduction of parasitic infections such as mechanization of soil, high use of antiparasitics, easy access to public health facilities, and sanitation conditions $\mathrm{s}^{3,4,17,18,29}$. In the present study, the low prevalence observed may be because most of those investigated possessed valid health cards and had some awareness of the transmission of diseases.

Therefore, in order to further reduce intestinal parasitic infections in food handlers, several strategies are recommended such as stool examinations with concentration methods every three months, public education, the application of health regulations, controlling the validity of health cards and training on parasitic infection transmission.

Also, since participation in training courses in environmental health increased awareness of the transmission of diseases $(p<0.05)$, it is recommended that further training courses will be held and food handlers are required to attend the courses. Participants infected by parasites were given advice on how to treat the infections. The findings of the present study can be used as a basis to develop preventive programs targeting food handlers because the spread of disease via them is a common problem worldwide. In this regard, the authors intend to use the findings of this study to support public health decision-making in the area of control strategies for intestinal parasitic infections.

\section{RESUMEN}

\section{La prevalencia de parásitos intestinales entre los manipuladores de alimentos en el oeste de Irán}

Infección parasitaria es uno de los problemas de salud humana, especialmente en los países en desarrollo. En este estudio, todas las tiendas de comida rápida, restaurantes, y tiendas de carne asada en Khorramabad (oeste de Irán) y todo el personal que trabaja en ellos, incluyendo 210 personas fueron seleccionadas a través de los censos y las heces fueron examinadas para detectar la presencia de parásitos. La prueba parasitológica directa de mojado de montaje, la tinción de Lugol's yodo, sedimentación formaldehído-éter y tricrómicas técnicas de tinción se realizaron sobre las muestras. Los datos fueron analizados con la prueba de chi-cuadrado y regresión logística seleccionado como el modelo analítico. Los resultados mostraron 19 (9\%) muestras de heces fueron positivos para diferentes parásitos intestinales. Los parásitos intestinales incluyen Giardia lamblia 2.9\%, Entamoeba coli $4.3 \%$, Blastocystis sp. $1.4 \%$, Hymenolepis nana $0.5 \%$. Hubo diferencia significativa entre la presencia de la tarjeta sanitaria válida, el conocimiento de la transmisión de los parásitos intestinales, la participación en cursos de formación en materia de salud ambiental con parásitos intestinales $(p<0.05)$. No hubo diferencia estadísticamente significativa entre la tasa de alfabetización y el sexo entre los pacientes infectados con parásitos intestinales $(p>0.05)$. Para controlar la infección parasitaria en los manipuladores de alimentos se recomiendan varias estrategias, tales como examen de heces cada tres meses, la educación pública, se aplican las normas sanitarias, el control de validez de la tarjeta sanitaria y la transmisión formación infección parasitaria. En este sentido, los resultados del presente estudio se pueden utilizar como una base para desarrollar programas de prevención 
dirigidos a los manipuladores de alimentos debido a la propagación de enfermedades a través de ellos es un problema común en todo el mundo.

\section{ACKNOWLEDGEMENTS}

The authors hereby thank the Deputy of Research and Technology and co-researchers of Lorestan University of Medical Sciences, as well as all the people who helped us in this research; their contributions are sincerely appreciated. The authors declare that no conflict of interests exists.

\section{REFERENCES}

1. Al-Zain B, Al-Hindi A. Distribution of Strongyloides stercoralis and other intestinal parasites in household in Beit-Lahia city, Gaza Strip, Palestine. Ann Alquds Med. $2005 ; 1: 48-52$.

2. Andargie G, Kassu A, Moges F, Tiruneh M, Huruy K. Prevalence of bacteria and intestinal parasites among food-handlers in Gondar town, northwest Ethiopia. J Health Popul Nutr. 2008;26:451-5.

3. Arani AS, Alaghehbandan R, Akhlaghi L, Shahi M, Lari AR. Prevalence of intestinal parasites in a population in south of Tehran, Iran. Rev Inst Med Trop Sao Paulo. 2008;50:145-9.

4. Ashtiani MT, Monajemzadeh M, Saghi B, Shams S, Mortazavi SH, Khaki S, et al. Prevalence of intestinal parasites among children referred to Children's Medical Center during 18 years (1991-2008), Tehran, Iran. Ann Trop Med Parasitol. 2011;105:507-12

5. Babiker MA, Ali MSM, Ahmed ES. Frequency of intestinal parasites among foodhandlers in Khartoum, Sudan. East Med Health J. 2009;15:1098-104.

6. Daryani A, Ettehad GH, Sharif M, Ghorbani L, Ziaei H. Prevalence of intestinal parasites in vegetables consumed in Ardabil, Iran. Food Control. 2008;19:790-4.

7. David TJ, William AP. Markell and Voge's Medical Parasitology. Ninth Ed. Toronto: Saunders Elsevier; 2006. Chapter 1.

8. Diaz E, Mondragon J, Ramirez E, Bernal R. Epidemiology and control of intestinal parasites with nitazoxanide in children in Mexico. Am J Trop Med Hyg. 2003;68:3845 .

9. Garcia LS. Diagnostic medical parasitology. $5^{\text {th }}$ ed. Washington: ASM Press; 2007.

10. Green L, Selman C, Banerjee A, Marcus R, Medus C, Angulo FJ, et al. Food service workers self reported food preparation practices: an EHS-Net study. Int J Hyg Environ Health. 2005;208:27-35

11. Hennessy TW, Cheng LH, Kassenborg H, Ahuja SD, Mohle-Boetani J, Marcus $\mathrm{R}$, et al. Egg consumption is the principal risk factor for sporadic Salmonella serotype Heidelberg infection: a case-control study in food net sites. Clin Infect Dis. 2004;38(Suppl 3):S237-43.

12. Idowu OA, Rowland SA. Oral fecal parasites and personal hygiene of food handlers in Abeokuta, Nigeria. Afr Health Sci. 2006;6:160-4.

13. Jacobsen KH, Ribeiro PS, Quist BK, Rydbeck BV. Prevalence of intestinal parasites in young Quichua children in the highlands of rural Ecuador. J Health Popul Nutr. 2007;25:399-405.

14. Kaferstein FK. Food safety as public health issue for developing countries. Geneva: WHO; 2003

15. Kheirandish F, Tarahi MJ, Haghighi A, Nazemalhosseini- Mojarad E, Kheirandish M. Prevalence of intestinal parasites in bakery workers in Khorramabad, Lorestan Iran. Iran J Parasitol. 2011;6:76-83.
16. Monzon RB, Sanchez AR, Tadiaman BM, Najos OA, Valencia EG, Rueda RR, et al. A comparison of the role of Musca domestica (Linnaeus) and Chrysomya megacephala (Fabricius) as mechanical vectors of helminthic parasites in a typical slum area of metropolitan Manila. Southeast Asian J Trop Med Public Health. 1991;22:222-8.

17. Mortean ECM, Falavigna DLM, Janeiro V, Falavigna-Guilherme AL, Gomes ML. Low intestinal parasites as an health indicator in a municipality of southern Brazil with intensive agricultural mechanization. SaBios: Rev Saúde Biol. 2012;7:23-9.

18. Nasiri V, Esmailnia K, Karim G, Nasir M, Akhavan O. Intestinal parasitic infection among inhabitants of Karaj City, Tehran province, Iran in 2006-2008. Korean J Parasitol. 2009;47:265-8.

19. Nyarango RM, Aloo PA, Kadiru EW, Nyanchongi BO. The risk of pathogenic intestinal parasite infections in Kisii Municipality, Kenya. BMC Public Health. 2008;8:237.

20. Okyay P, Ertug S, Gultekin B, Onen O, Beser E. Intestinal parasites prevalence and related factors in school children, a western city sample -Turkey. BMC Publ Health. 2004;4:64

21. Quihui L, Valencia ME, Crompton DW, Phillips S, Hagan P, Morales G, et al. Role of the employment status and education of mothers in the prevalence of intestinal parasitic infections in Mexican rural schoolchildren. BMC Publ Health. 2006;6:225.

22. R Development Core Team. R: a language and environment for statistical computing Vienna: R Foundation for Statistical Computing; 2012.

23. Saab BR, Musharrafieh U, Nassar NT, Khogali M, Araj GF. Intestinal parasites among presumably healthy individuals in Lebanon. Saudi Med J. 2004;25:34-7.

24. Saeed HA, Hamid HH. Bacteriological and parasitological assessment of food handlers in the Omdurman area of Sudan. J Microbiol Immunol Infect. 2010;43:70-3.

25. Saygi G, Ozcelik S, Poyraz O. A survey of intestinal parasites in student of adults educational center in Sivas, Turkey. J Egypt Soc Parasitol. 1995;25:303-10.

26. Sayyari AA, Imanzadeh F, Bagheri-Yazdi SA, Karami H, Yaghoobi M. Prevalence of intestinal parasitic infections in the Islamic Republic of Iran. East Mediterr Health J. 2005; 11:377-83

27. Scott E. Food safety and foodborns diseases in $21^{\text {th }}$ century homes. Can J Infect Dis 2003; $14: 277-80$

28. Tappeh KhH, Mohammadzadeh H, Rahim RN, Barazesh A, Khashaveh Sh, Taherkhani H. Prevalence of intestinal parasitic infections among mentally disabled children and adults of Urmia, Iran. Iran J Parasitol. 2010;5:60-4.

29. Takizawa MG, Falavigna DL, Gomes ML. Enteroparasitosis and their ethnographic relationship to food handlers in a tourist and economic center in Parana, Southern Brazil. Rev Inst Med Trop Sao Paulo. 2009;51:31-5.

30. World Health Organization. Report on global surveillance of epidemic-prone infectious diseases-leishmaniasis. 2006. Available from: http://www.who. int/csr/ resources/publications/CSR_ISR_2000_1leish/en/index.html

31. World Health Organization. Control of leishmaniasis. Report by the secretariat. 2007. Available from: http://apps.who.int/gb/ebwha/pdf_files/WHA6 0/A60_10-en.pdf

32. World Health Organization. Medios auxiliaries para el diagnostico de las parasitosis intestinales. Geneva: WHO; 1994.

Received: 4 November 2012

Accepted: 25 June 2013 